\title{
ZrMoN FILMS ON 304 STAINLESS STEEL AS BIPOLAR PLATES FOR PEMFCs USING PHYSICAL-VAPOR-DEPOSITION (PVD) TECHNOLOGY
}

\author{
ZrMoN PREVLEKE NA NERJAVNEM JEKLU 304 KOT BIPOLARNE \\ PLOŠČE ZA PEMFC-je Z UPORABO TEHNOLOGIJE NANAŠANJA \\ IZ PARNE FAZE (PVD)
}

\author{
Chuan-Bo Zheng, Xi Chen \\ Jiangsu University of Science and Technology, School of Material Science and Engineering, Zhenjiang 212003, China \\ 15952802516@139.com
}

Prejem rokopisa - received: ;2016-11-09 sprejem za objavo - accepted for publication: 2017-01-20

doi:10.17222/mit.2016.316

\begin{abstract}
ZrMoN films were deposited on a 304 stainless-steel (SS304) substrate with a radio-frequency (RF) reactive magnetron-sputtering system and the properties were changed by adjusting the power of the Mo target. The corrosion behaviors of the ZrMoN films were investigated with potentiodynamic tests and electrochemical impedance spectroscopy (EIS) under the condition of an aerated $0.5 \mathrm{M} \mathrm{H}_{2} \mathrm{SO}_{4}+1,99 \mathrm{mg} / \mathrm{L} \mathrm{NaF}$ solution at $70{ }^{\circ} \mathrm{C}$. The results revealed that all samples with $\mathrm{ZrMoN}$ films have good hydrophobicity. The XRD test showed that the $\mathrm{ZrMoN}$ film is the substitutional solid solution of Mo atoms into ZrN films. As an overall evaluation, the power of the Mo target is $30 \mathrm{~W}$. A coated sample displays the best corrosion resistance in the cathode of the PEMFC environment when the power of the Mo target is considered, which indicates that with an increase of the power of the Mo target, the solid solubility also increases; but with a continuous increase of the Mo-target power, the solubility increases and a lattice distortion also occurs, leading to an increase in defects.

Keywords: ZrMoN, corrosion behavior, bipolar-plate material, physical-vapor-deposition technology (PVD)

ZrMoN prevleke so bile nanešene na substrat 304 nerjavnega jekla (SS 304) z radiofrekvenčnim reaktivnim (angl. RF) magnetronskim naprševalnikom in lastnosti so bile spremenjene s prilagoditvijo moči Mo tarče. Korozijsko obnašanje prevlek ZrMoN smo raziskovali s potenciodinamskimi preizkusi in elektrokemijsko impedančno spektroskopijo (EIS) v raztopini $0,5 \mathrm{M} \mathrm{H}_{2} \mathrm{SO}_{4}$ $+1,99 \mathrm{mg} / \mathrm{L} \mathrm{NaF}$ pri temperaturi $70^{\circ} \mathrm{C}$. Rezultati so pokazali, da imajo vsi vzorci z ZrMoN prevlekami dobro hidrofobnost. XRD-analiza kaže, da je prevleka ZrMoN nadomestna trdna raztopina atomov Mo v ZrN plasti. Rezultati kažejo najboljšo korozijsko odpornost na katodi v okolju PEMFC pri moči Mo tarče $30 \mathrm{~W}$, kar kaže, da se s povečanjem moči Mo povečuje tudi trdna topnost. Vendar pa se $s$ kontinuiranim povečevanjem moči Mo tarče neprestano povečuje tudi topnost, zato pride do popačenja kristalne mreže, kar povzroči povečanje napak.

Ključne besede: ZrMoN, korozijsko obnašanje, bipolarni material, tehnologija nanašanja iz parne faze (PVD)
\end{abstract}

\section{INTRODUCTION}

The whole world requires the pollution to be reduced due to the global warming, caused by greenhouse gases such as $\mathrm{CO}_{2}$, NOx and Sox. ${ }^{1,2}$ The proton-exchangemembrane fuel cell (PEMFC) is considered to be a competitive candidate as the next-generation power source for automotive, stationary and portable applications due to its prominent characteristics including a quick startup, zero emission, high efficiency, etc. ${ }^{3-5}$ It is a device that directly and efficiently converts chemical energy into electricity. ${ }^{6}$ One of the most expensive and heaviest components in a PEMFC stack is the bipolar plate (BPP). ${ }^{7}$ The BPP plays several important roles in the whole fuel-cell stack, affecting its total weight, volume and cost. In order to perform these functions, a BPP should feature high corrosion resistance in PEMFC environments, good electrical conductivity, high mechanical strength, high capability of gas separation, low cost and easily machining. ${ }^{8}$ Metallic BPPs have been widely accepted due to their good electrical conductivity, good mechanical properties, processing performance and low production cost. However, during the fuel-cell operating condition, a sample exposed to a highly acidic medium ( $\mathrm{pH} 2-3$ ) containing ions like $\mathrm{F}^{-}, \mathrm{SO}_{4}{ }^{2-}$ and $\mathrm{HCO}_{3}{ }^{-}$, undergoes severe corrosion on its surface, which results in a loss of the power output of the PEMFC. ${ }^{9}$

In general, transition-metal nitride films are chemically inert and thermally stable. However, an attack of the corrosive medium on the substrate is severe due to the defects within the film (such as micro-cracks, pores, pinholes, grain boundaries, etc.). ${ }^{10}$ These defects create a direct path between the exposed substrate and the corrosive medium, thus affecting the electrochemical behavior of these films. Among the large refractory-metal carbonitrides, $\mathrm{ZrCN}$ is an attractive material because of its excellent chemical and physical properties, such as a relatively low electrical resistivity and high corrosion resistance. ${ }^{11} \mathrm{Zr}$ alloys undergo corrosion in high-temperature water and steam, with rapid initial corrosion forming an oxide layer which causes the oxidation rate to slow down. This is because the migration of charged species (oxygen ions and electrons) across the oxide thickness is inhibited. As corrosion progresses, a critical ox- 
C. B. ZHENG, X. CHEN: ZrMoN FILMS ON 304 STAINLESS STEEL AS BIPOLAR PLATES FOR PEMFCs ...

ide thickness is reached, at which the protection of the oxide layer breaks down and a rapid increase in the oxidation rate is observed. The breakdown is known as 'the transition' and it is followed by a reduction in the oxidation rate as a new protective oxide layer forms. ${ }^{12}$ Molybdenum (Mo) is considered as one of the principal alloying elements for stainless steels and its beneficial effects on the corrosion resistance were most thoroughly investigated. ${ }^{13-15}$ It is well known that Mo enhances the resistance to pitting corrosion and expands the passive region in sulfuric acid, making types 316 and 317 suitable for $90 \%$ mass fractions of $\mathrm{H}_{2} \mathrm{SO}_{4}$ at ambient temperature. The corrosion behavior of single-layer films like TiN and CrN was widely reported; ${ }^{16-18}$ however, very few studies reported on $\mathrm{ZrMoN}$ films.

In order to improve the corrosion resistance of metallic BPPs, many attempts were made by employing different surface-modification methods. The formation of a protective film on the BPPs with physical-vapor deposition (PVD) is proven to be an effective method and has been extensively studied. ${ }^{19-24}$ Many researchers focused on the multilayer, while fewer on the composite film.

Thus, in this study, ZrMoN films were deposited on SS304 using an RF magnetron-sputtering system and the properties were changed by adjusting the power of the Mo target. The effects of the Mo-target power on the corrosion behavior were investigated by simulating the cathode environment of the PEMFC.

\section{EXPERIMENTAL PART}

\subsection{ZrMoN films and electrode preparation}

The substrate (a $15 \mathrm{~mm}$ diameter and $2 \mathrm{~mm}$ thickness) used was SS304 consisting of $0.08 \%$ amount fraction of $\mathrm{C}, 1.00 \%$ amount fraction of $\mathrm{Si}, 2.00 \%$ amount fraction of $\mathrm{Mn}, 0.045 \%$ amount fraction of $\mathrm{P}, 0.03 \%$ amount fraction of S, 18-20.\% amount fraction of Cr, 8.0-10.5\% amount fraction of $\mathrm{Ni}$ and Fe balance. ZrMoN films were deposited on the substrate surface using the PVD technology, and the properties were changed by adjusting the power of the Mo target. The film was deposited using an RF magnetron-sputtering system (JGP450, SKY Technology Development Co., Ltd, CAS, China), which consists of two RF sputtering guns, each of them mounted on water-cooled target holders. The distance between the substrate holder and the targets was $11 \mathrm{~mm}$. The substrates were cleaned with successive rinsing in ultrasonic baths of deionized water, ethyl alcohol absolute $\left(\mathrm{C}_{2} \mathrm{H}_{6} \mathrm{O}=99.7 \%\right)$ and acetone and blown dry with dry air. The $\mathrm{Zr}$ target and the Mo target with the same purities of $99.9 \%$ were positioned $11 \mathrm{~mm}$ from the substrate. Argon gas and nitrogen gas of very high purity $(99.999 \%)$ were introduced. The base pressure was less than $6.0 \times 10^{-4} \mathrm{~Pa}$. Prior to deposition, the targets were cleaned by pre-sputtering for $10 \mathrm{~min}$, while the substrate was isolated from the plasma with a shutter. More parameters for the deposition of the ZrMoN films are listed in Table $\mathbf{1 .}$
Table 1: Deposition parameters for ZrMoN films

\begin{tabular}{|c|c|}
\hline ZrMoN films & Parameters \\
\hline Base pressure & Less than $6.0 \times 10^{-4} \mathrm{~Pa}$ \\
\hline Total pressure & $0.3 \mathrm{~Pa}$ \\
\hline Flow rate of Ar and $\mathrm{N}_{2}$ & $10: 3$ \\
\hline Zr-target power (RF) & $150 \mathrm{~W}$ \\
\hline Mo-target power (RF) & $20 \mathrm{~W}, 30 \mathrm{~W}, 50 \mathrm{~W}, 90 \mathrm{~W}$ \\
\hline Deposition temperature & Room temperature \\
\hline Deposition time & $2 \mathrm{~h}$ \\
\hline
\end{tabular}

\subsection{Contact-angle test}

Wettability has a strong effect on the cell performance, particularly at high current densities. A high contact angle implies a high surface energy and low surface wettability of a material. ${ }^{25}$ Water contact angles (WCA) were measured using a drop shape analyzer (DSA) (JC2000D, Powereach Corporation, Shanghai, China). The volume of a water droplet was $\approx 4 \mu \mathrm{L}$ and the average values of 10 measurements were reported as the water contact angle.

\subsection{Structural characterization}

The samples were sealed in rubber mud; XRD data of the films were reordered with SHIMADZU XRD-6000 ray diffraction $\left(\mathrm{XRD}, \mathrm{Cu}-K_{\alpha}=1\right.$ ). The working voltage and the current for the diffractometer were set at $40 \mathrm{kV}$ and $30 \mathrm{~mA}$, respectively. The scanning range $(2 \theta)$ was $20^{\circ} \sim 80^{\circ}$.

The thickness and surface morphology of the films were observed using JSM-6480 scanning electron microscopy.

\subsection{Electrochemical corrosion test}

The corrosion behavior of ZrMoN-coated and uncoated samples under the cathode of PEMFC were studied; the electrolyte was a $0.5 \mathrm{M} \mathrm{H}_{2} \mathrm{SO}_{4}+2 \mathrm{mg} / \mathrm{L} \mathrm{NaF}$ solution at $70{ }^{\circ} \mathrm{C}$, and the air was bubbled through the test. A three-electrode electrochemical cell was used, together with a platinum counter electrode and an $\mathrm{Hg} / \mathrm{HgO}$ saturated $\mathrm{KCl}$ electrode as the reference electrode. The sample to be tested was the working electrode. Samples were loaded in silicon rubber and the surface area exposed to the corrosive medium was approximately $0.25 \mathrm{~cm}^{2}$. The samples were kept in the test solution for a period of time before the potentiodynamic polarization study in order to establish the open-circuit potential $\left(E_{\mathrm{ocp}}\right)$ or the steady-state potential. ${ }^{26}$

\subsubsection{Potentiodynamic polarization}

The sweep range was $-0.4 \mathrm{~V} \sim 1.5 \mathrm{~V}$ (relative to the $\left.E_{\text {ocp}}\right)$ and the sweep rate was $1 \mathrm{mv} / \mathrm{s}$. Tafel plots were obtained after the electrochemical measurements. The corrosion potential $\left(E_{\text {corr }}\right)$ and the corrosion-current density $\left(i_{\text {corr }}\right)$ were deduced from the Tafel plots (that is, $\log i$ vs. E plot). The polarization resistance $\left(R_{\mathrm{p}}\right)$ was measured 
C. B. ZHENG, X. CHEN: ZrMoN FILMS ON 304 STAINLESS STEEL AS BIPOLAR PLATES FOR PEMFCs ...

using linear sweep voltammetry and calculated from the Stern-Geary equation, with Equation (1):27

$$
R_{\mathrm{p}}^{-1}=2.303 i_{\text {corr }}\left(\frac{1}{b_{\mathrm{a}}}+\frac{1}{\left|b_{\mathrm{c}}\right|}\right)
$$

$R_{\mathrm{p}}$ in Equation (1) relates to the corrosion behavior of the test materials; the $i_{\text {corr }}$ and the Tafel constants $b_{\mathrm{a}}$ and $b_{\mathrm{c}}$ can be measured from the experimental data. The Tafel constant $b_{\mathrm{c}}$ is negative; its absolute value was used in Equation (1).

\subsubsection{Electrochemical impedance spectroscopy}

The impedance measurements were made at the open-circuit potential and the applied alternating potential had an amplitude of $10 \mathrm{mV}$. The spectrum was recorded in a frequency range of $10 \mathrm{mHz} 100 \mathrm{KH}$. After each experiment, the impedance data was displayed as Nyquist plots. The Nyquist plot is a plot of the real ( $\left.Z^{\prime}\right)$ vs. imaginary impedance (Z"). From this plot at a high frequency, the value of the solution resistance $\left(R_{\mathrm{s}}\right)$ was obtained and at a low frequency, the charge transfer resistance $\left(R_{\mathrm{ct}}\right)$ was deduced. The data were analyzed using the Zview software.

\section{RESULTS AND DISCUSSION}

\subsection{Contact-angle test}

Table 2 shows the contact angles of the $\mathrm{ZrMoN}$ coated samples with water. Due to the liquid water, the battery cannot be discharged in time and the water enters the porous electrode blocking the reaction gas path and reducing the catalytic activity area. This results in a decreased cell performance, and the liquid water attached to the surfaces of the metallic bipolar plates accelerates the corrosion of the bipolar plates. ${ }^{28}$ So, the bipolar-plate material should have low surface wettability. On Table 2,

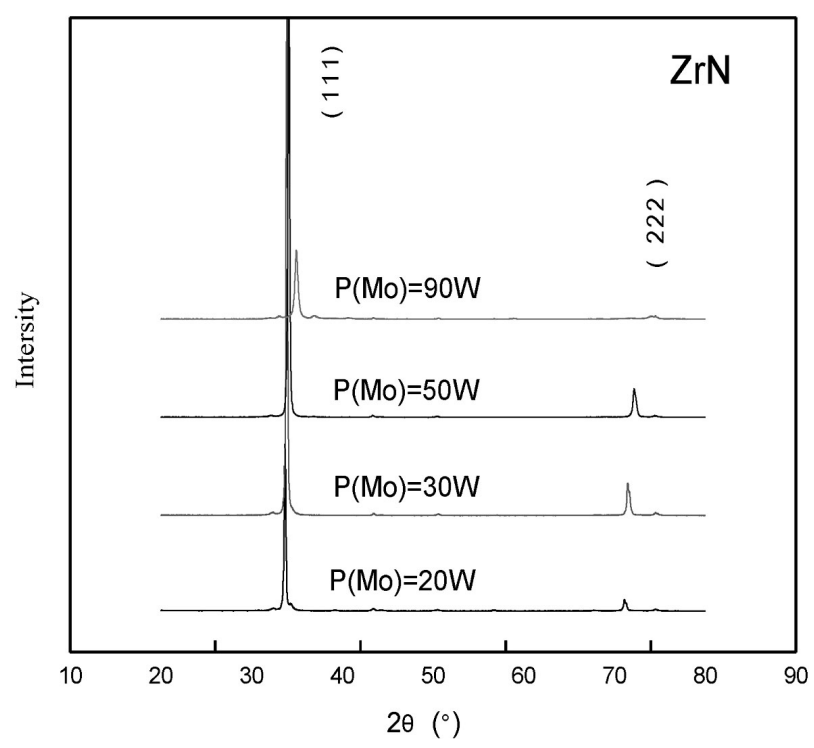

Figure 1: XRD test results for $\mathrm{ZrMoN}$ films the contact angles are nearly $90^{\circ}$. It is obvious that the ZrMoN coated samples have high contact angles on the surfaces, which shows good hydrophobicity.

Table 2: Contact-angle-measurement results of $\mathrm{ZrMoN}$ films

\begin{tabular}{|c|l|c|}
\hline \multirow{2}{*}{ Films } & \multicolumn{2}{|c|}{ Contact angle } \\
\hline \multirow{3}{*}{ ZrMoN films } & $\mathrm{P}(\mathrm{Mo})=20 \mathrm{~W}$ & $96.11^{\circ}$ \\
\cline { 2 - 3 } & $\mathrm{P}(\mathrm{Mo})=30 \mathrm{~W}$ & $94.45^{\circ}$ \\
\cline { 2 - 3 } & $\mathrm{P}(\mathrm{Mo})=50 \mathrm{~W}$ & $97.61^{\circ}$ \\
\cline { 2 - 3 } & $\mathrm{P}(\mathrm{Mo})=90 \mathrm{~W}$ & $93.83^{\circ}$ \\
\hline
\end{tabular}

\subsection{XRD test}

Crystal phases of the ZrMoN coated samples were analyzed with XRD patterns and the results are presented in Figure 1. This figure shows that the films mainly include $\mathrm{ZrN}$ phases; there are no $\mathrm{MoN}$ and Mo phases in the films, and it is obvious that a $\mathrm{ZrMoN}$ film is the substitutional solid solution of Mo atoms into $\mathrm{ZrN}$ films. The XRD patterns show that there are two main diffrac-

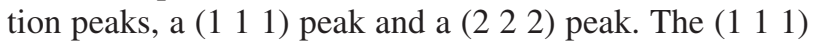
peak is the strongest; therefore, the growth orientation of the $\mathrm{ZrMoN}$ film is mainly in the $\left(\begin{array}{lll}1 & 1 & 1\end{array}\right)$ direction.

\subsection{SEM analysis}

Figure 2 is a SEM micrograph of the ZrMoN film where the Mo-target power is $20 \mathrm{~W}$. The formation of pinholes is nearly impossible to avoid. This is because the coated surfaces are always non-uniform and because the coating tends to grow in a non-uniform manner. Various growth models were developed to describe the growth process. ${ }^{29}$ A general feature of these models is the fact that after the original nucleation stage, the growth takes place in isolated islands, which then grow together, leaving the voids between them. The general growth morphology of the coatings is typically columnar. Although various techniques can be used to minimize the number of pinholes, they usually cannot be totally eliminated. They occur commonly in all kinds of coatings on all kinds of substrates. ${ }^{30}$

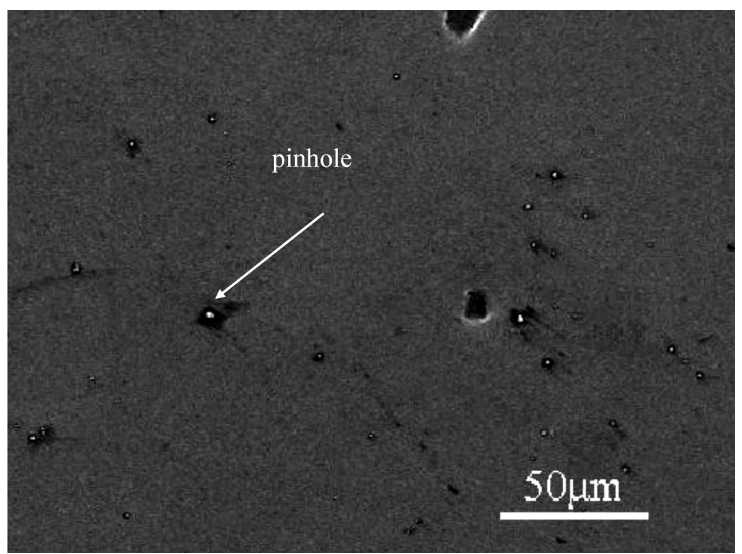

Figure 2: SEM micrograph of the $\mathrm{ZrMoN}$ film where the power of Mo target is $20 \mathrm{~W}$ 


\section{MATERIALI IN TEHNOLOGIJE/MATERIALS AND TECHNOLOGY (1967-2017) - 50 LET/50 YEARS}

C. B. ZHENG, X. CHEN: ZrMoN FILMS ON 304 STAINLESS STEEL AS BIPOLAR PLATES FOR PEMFCs ...

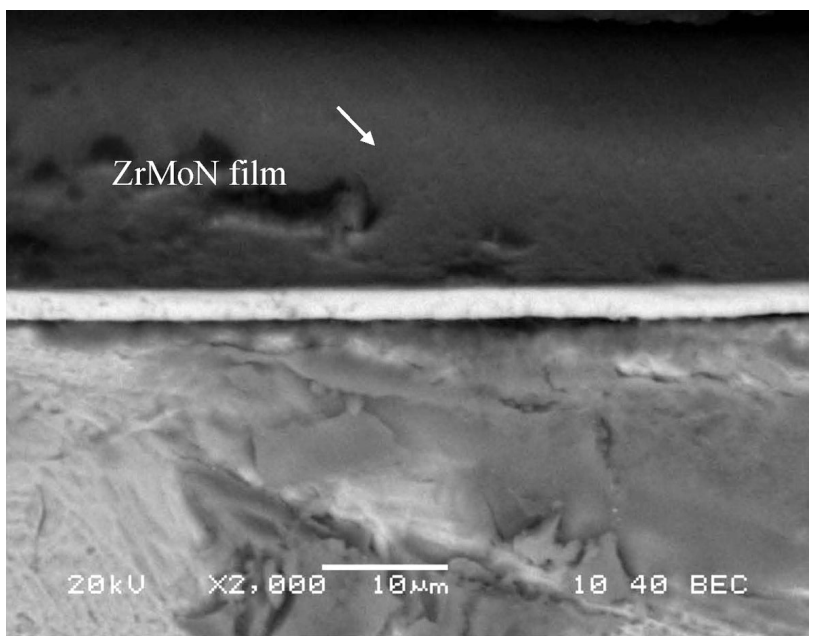

Figure 3: Cross-sectional view of the $\mathrm{ZrMoN}$ film where the power of Mo target is $50 \mathrm{~W}$

In this study, the coating layers also had such defects, arising from the coating process or the substrate, although relatively dense coatings were obtained. A SEM micrograph of the defects in the coating layer of the ZrMoN film is given in Figure 2. It can be clearly seen from Figure 2 that there is a pinhole in the film, shown as a black hole, due to the columnar growth during the coating process. It is indicated that the electrolyte may penetrate through the pores and the micro-pores in the film to the substrate, causing corrosion. ${ }^{31-33}$ Figure 3 presents a cross-sectional view of the $\mathrm{ZrMoN}$ film with the power of the Mo target of $50 \mathrm{~W}$ and a thickness of $2.3 \mu \mathrm{m}$.

\subsection{Potentiodynamic tests}

Table 3 shows the $E_{\text {ocp }}$ values of the $\mathrm{ZrMoN}$ coated and uncoated samples. Except for the sample with $20 \mathrm{~W}$, the $E_{\text {ocp }}$ values for the samples with a higher Mo-target power are higher than that of the uncoated sample, showing a better corrosion resistance than the uncoated sample. Figure 4 shows potentiodynamic polarization curves of the ZrMoN coated and uncoated samples in a simulated PEMFC working solution. Table 4 lists polarization parameters of the $\mathrm{ZrMoN}$ coated and uncoated samples. It is clear from a comparison of the $E_{\text {corr }}, i_{\text {corr }}$ and $R_{\mathrm{p}}$ values of the samples, with the power of the Mo target increasing from $20 \mathrm{~W}$ to $90 \mathrm{~W}$, that there is a gradual shift in the $E_{\text {corr }}$ values towards the positive side (from -0.395 to -0.0347 ), while the $i_{\text {corr }}$ decreases gradually from 18.1 to 0.0169 , and the $R_{\mathrm{p}}$ is gradually improved. The ZrMoN films exhibited much lower $i_{\text {corr }}$ values and nobler $E_{\text {corr }}$ under the simulated PEMFC working condition. These results revealed that the $\mathrm{ZrMoN}$ films markedly enhanced the corrosion resistance of SS304.

According to the technical index of DOE published in $2006^{34}$, relating to a sample in the cathode of a PEMFC environment (about 0.6V vs. SCE), the passivation-current density must be less than $1.0 \mu \mathrm{A} \mathrm{cm}^{-2}$; thus, a vertical line was set as the standard in Figure 4. Table 5 shows the passive-current density of the samples in the PEMFC cathode. When the power of the Mo target is $30 \mathrm{~W}$, the sample has a good corrosion resistance in the PEMFC environment, and it is also close to the technical index of DOE. However, a significant finding was that the other coated samples had a lower corrosion resistance. They even surprisingly exhibited higher corrosion-current densities than the uncoated sample, resulting in a need for further investigation. This finding indicates that with an increase in the power of the Mo target, the solid solubility also increases; when the power of the Mo target is $30 \mathrm{~W}$, the solid solubility in the medium has good corrosion resistance. However, with a continuous increase of the Mo-target power, the solubility increases and a lattice distortion occurs, which will also lead to an increase in defects.

Table 3: $E_{\text {ocp }}$ of $\mathrm{ZrMoN}$ coated and uncoated samples

\begin{tabular}{|c|c|c|c|c|c|}
\hline $\begin{array}{c}\text { ZrMoN } \\
\text { films }\end{array}$ & $\begin{array}{c}\mathrm{P}(\mathrm{Mo})= \\
20 \mathrm{~W}\end{array}$ & $\begin{array}{c}\mathrm{P}(\mathrm{Mo})= \\
30 \mathrm{~W}\end{array}$ & $\begin{array}{c}\mathrm{P}(\mathrm{Mo})= \\
50 \mathrm{~W}\end{array}$ & $\begin{array}{c}\mathrm{P}(\mathrm{Mo})= \\
90 \mathrm{~W}\end{array}$ & uncoated \\
\hline$E_{\text {ocp }} /(\mathrm{V})$ & -0.377 & -0.179 & 0.0428 & 0.152 & -0.1986 \\
\hline
\end{tabular}

Table 4: Polarization parameters of ZrMoN coated and uncoated samples

\begin{tabular}{|l|c|c|c|c|c|}
\hline ZrMoN films & $\begin{array}{c}i_{\text {corr }} \\
\left(\mu \mathrm{A} / \mathrm{cm}^{2}\right)\end{array}$ & $\begin{array}{c}E_{\text {corr }} \\
(\mathrm{V})\end{array}$ & $\begin{array}{c}b_{\mathrm{a}} \\
\left(\mathrm{A} / \mathrm{cm}^{2}\right)\end{array}$ & $\begin{array}{c}b_{\mathrm{c}} \\
\left(\mathrm{A} / \mathrm{cm}^{2}\right)\end{array}$ & $\begin{array}{c}R_{\mathrm{p}} \\
\left(\mathrm{A} / \mathrm{cm}^{2}\right)\end{array}$ \\
\hline $\mathrm{P}(\mathrm{Mo})=20 \mathrm{~W}$ & 18.1 & -0.395 & 0.4949 & 0.34343 & 0.00486 \\
\hline $\mathrm{P}(\mathrm{Mo})=30 \mathrm{~W}$ & 0.0923 & -0.187 & 0.1319 & 0.1637 & 0.3436 \\
\hline $\mathrm{P}(\mathrm{Mo})=50 \mathrm{~W}$ & 0.0670 & -0.0368 & 0.2132 & 0.2187 & 0.6997 \\
\hline $\mathrm{P}(\mathrm{Mo})=90 \mathrm{~W}$ & 0.0169 & -0.0347 & 0.0636 & 0.0574 & 0.7752 \\
\hline
\end{tabular}

Table 5: Passivation-current density regarding $0.6 \mathrm{~V}$ vs. SCE of ZrMoN coated and uncoated samples

\begin{tabular}{|c|c|c|c|c|c|}
\hline $\begin{array}{c}\text { ZrMoN } \\
\text { films }\end{array}$ & $\begin{array}{c}\mathrm{P}(\mathrm{Mo})= \\
20 \mathrm{~W}\end{array}$ & $\begin{array}{c}\mathrm{P}(\mathrm{Mo})= \\
30 \mathrm{~W}\end{array}$ & $\begin{array}{c}\mathrm{P}(\mathrm{Mo})= \\
50 \mathrm{~W}\end{array}$ & $\begin{array}{c}\mathrm{P}(\mathrm{Mo})= \\
90 \mathrm{~W}\end{array}$ & uncoated \\
\hline $\begin{array}{c}(\lg i) \\
i /\left(\mathrm{A} / \mathrm{cm}^{2}\right)\end{array}$ & -3.943 & -5.526 & -4.936 & -3.017 & -5.281 \\
\hline
\end{tabular}

As mentioned earlier, the formation of coating defects is almost impossible to avoid totally. Consequently,

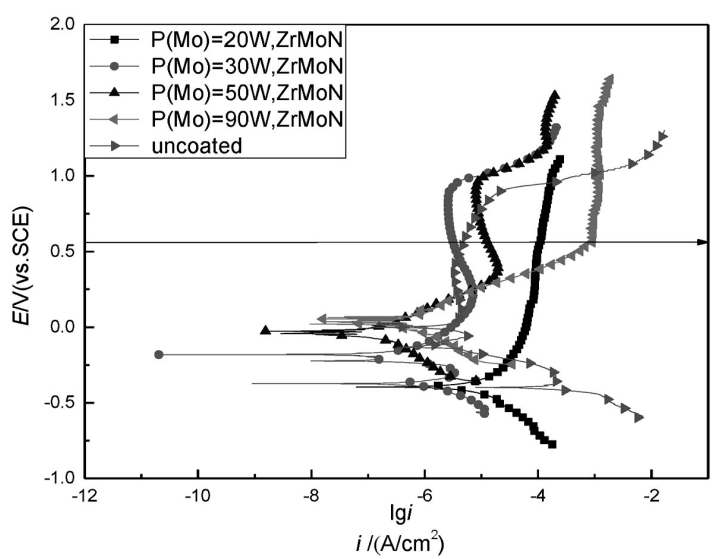

Figure 4: Potentiodynamic polarization curves of $\mathrm{ZrMoN}$ coated and uncoated samples (the cathode condition) 
when subjected to a corrosive atmosphere, coated samples form galvanic cells at the defects near the interface due to an electrochemical difference between the $\mathrm{ZrMoN}$ film and the substrate. Once aggressive ions such as $\mathrm{SO}_{4}{ }^{2-}$ penetrate the film through these small channels, driven by capillary forces, the area is exposed to anodic dissolution, which usually extends laterally along the interface between the film and the substrate. Finally, the formed pits link up with each other, causing a removal of the entire coating by flaking, ${ }^{35}$ which causes the abovementioned corrosion process. As an overall evaluation, the power of the Mo target is $30 \mathrm{~W}$. The coated sample displays the best corrosion resistance in the cathode of the PEMFC environment when the power of the Mo target is considered.

\subsection{EIS tests}

Figures 5 and $\mathbf{6}$ show the Nyquist and Bode plots for of the ZrMoN coated and uncoated samples. The EIS data are displayed in Table 6. The Nyquist plots (Figure 5) show the presence of a single semicircle for the ZrMoN coated samples, which may be attributed to the short exposure time in the corrosive medium. The Bode plots (Figure 5a) show that the absolute impedance increases in the same order. Figure $\mathbf{5 b}$ shows that the phase angles of all the samples are nearly $80^{\circ}$. In this study, the equivalent-circuit diagram used in the experiment is shown in Figure 7. ${ }^{26}$ The equivalent circuit for the uncoated sample is shown in Figure 7a. It consists of a double layer capacitance $\left(Q_{\mathrm{dl}}\right)$, which is parallel to the charge transfer resistance $\left(R_{\mathrm{ct}}\right)$; both of them are associated with the solution resistance $\left(R_{\mathrm{S}}\right)$ between the working electrode (WE) and the tip of the Luggin capillary. $Q$ stands for the constant phase element, which accounts for the deviations from the ideal dielectric behavior related to surface inhomogeneities. The value of $n$ is obtained from the slope of the $\log |Z|$ vs. $\log f$ plot. The phase angle $(\theta)$ can vary between $90^{\circ}$ (for a perfect ca-

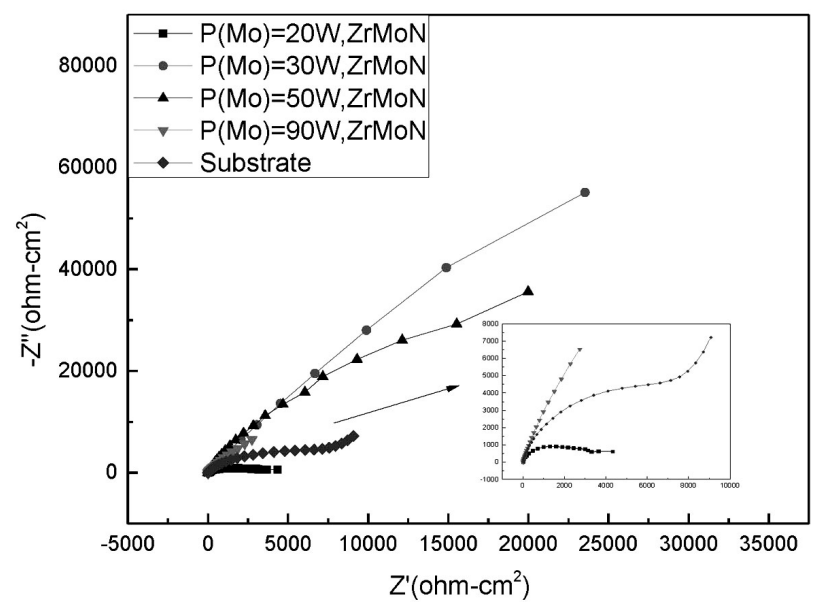

Figure 5: Impedance spectra of samples with ZrMoN films and substrate pacitor $(n=1))$ and $0^{\circ}($ for a perfect resistor $(n=0))$. In the present study, it represents a somewhat leaky capacitor with $n=0.85$. The $C_{\mathrm{dl}}$ is, therefore, replaced with the constant phase element when $n<1$.

The CDC for the equivalent circuit proposed for a mild steel substrate is $R(Q R)$. The proposed equivalent circuit for the PVD coating on the steel substrate with defects is shown in Figure 7b. Due to the low film thickness, when the coated sample is immersed in the electrolyte, the corrosion is expected to initiate rapidly at the pores present in the film. This leads to the formation of localized galvanic cells, which dominate the galvanic corrosion process. ${ }^{19}$ In such cases, the electrochemical interface can be divided into the sub-interface electrolyte/coating and the electrolyte/substrate. For the EIS data simulation, the equivalent-circuit model for the coated samples proposed by V. K. William Grips ${ }^{26}$ is used in this study, describing the mechanism of an electrochemical reaction. Therefore, the electrolyte can penetrate through the coating and attack the steel substrate. As the experiments are bubbled with air, the corrosion rate is limited by the slow diffusion of the electrolyte and oxygen through the defects in the film. This behavior can be described using a finite-length diffusion process.
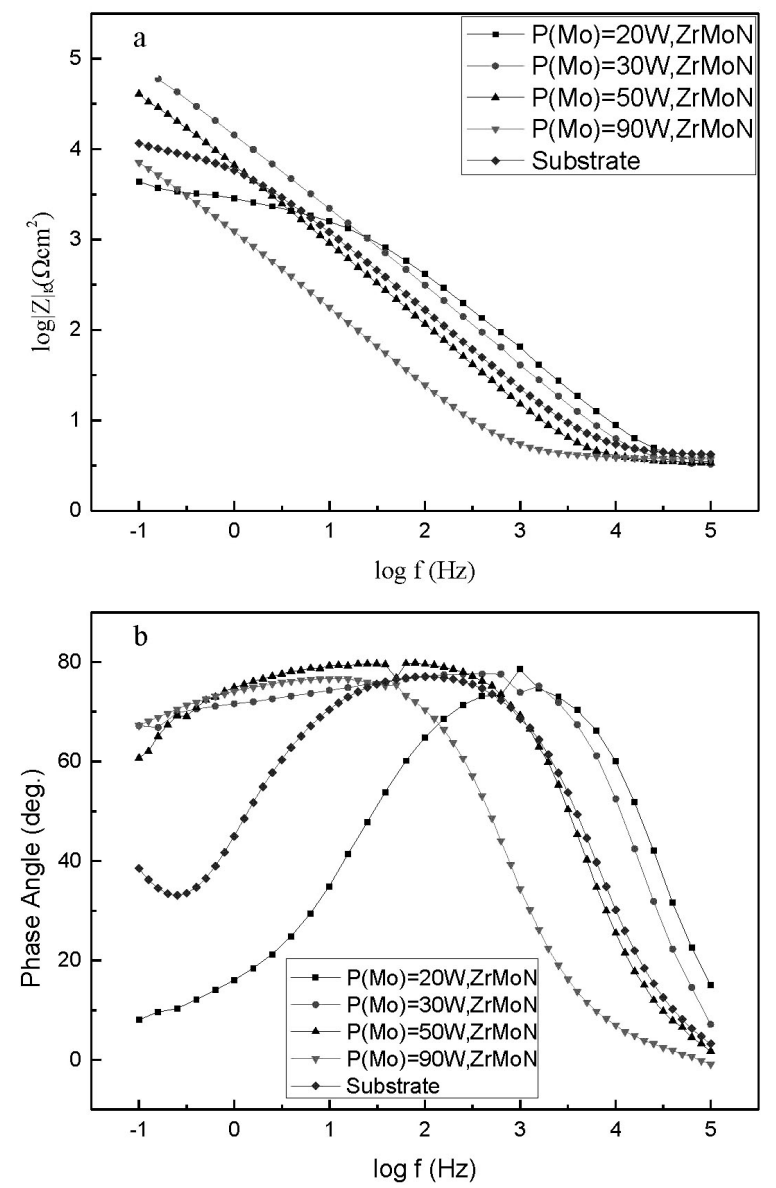

Figure 6: a) Bode plots $(\log |\mathrm{Z}|$ vs. $\log f$ ) of samples with $\mathrm{ZrMoN}$ films and substrate, b) Bode plots (phase angle vs. $\log f$ ) of samples with $\mathrm{ZrMoN}$ films and substrate 


\section{MATERIALI IN TEHNOLOGIJE/MATERIALS AND TECHNOLOGY (1967-2017) - 50 LET/50 YEARS}

C. B. ZHENG, X. CHEN: ZrMoN FILMS ON 304 STAINLESS STEEL AS BIPOLAR PLATES FOR PEMFCs ...

Table 6: EIS data obtained with an equivalent-circuit simulation of $\mathrm{ZrMoN}$ coated and uncoated samples

\begin{tabular}{|c|c|c|c|c|c|c|c|c|c|}
\hline ZrMoN films & $\begin{array}{l}R_{\mathrm{s}} \\
(\Omega)\end{array}$ & $\begin{array}{c}Q_{\text {film }}-Y_{0} \\
\left(\mathrm{~s}-\sec ^{\wedge} \mathrm{n}\right)\end{array}$ & $\begin{array}{c}n_{\text {film }} \\
(0<\mathrm{n}<1)\end{array}$ & $\begin{array}{l}R_{\text {pore }} \\
(\Omega)\end{array}$ & $\begin{array}{c}Q_{\mathrm{dl}}-Y_{0} \\
\left(\mathrm{~s}-\sec ^{\wedge} \mathrm{n}\right)\end{array}$ & $\begin{array}{c}n_{\mathrm{dl}} \\
(0<\mathrm{n}<1)\end{array}$ & $\begin{array}{l}R_{\mathrm{ct}} \\
(\Omega)\end{array}$ & $\begin{array}{c}O-Y_{0} \\
\left(\mathrm{~s}-\sec ^{\wedge} .5\right)\end{array}$ & $\begin{array}{c}B \\
\left(\sec ^{\wedge} .5\right)\end{array}$ \\
\hline $\mathrm{P}(\mathrm{Mo})=20 \mathrm{~W}$ & 3.219 & $\begin{array}{c}4.706 \\
\text { E-6 }\end{array}$ & 0.923 & 0.016 & $\begin{array}{l}5.47 \\
\text { E-5 }\end{array}$ & 0.383 & 3.808 & $\begin{array}{l}1.21 \\
\text { E-3 }\end{array}$ & 1.226 \\
\hline $\mathrm{P}(\mathrm{Mo})=30 \mathrm{~W}$ & 3.115 & $\begin{array}{c}1.391 \\
\text { E-6 }\end{array}$ & 0.754 & 0.149 & $\begin{array}{l}2.35 \\
\text { E-6 }\end{array}$ & 0.997 & $\begin{array}{c}1.158 \\
\text { E6 }\end{array}$ & 2.909 & $\begin{array}{c}1.844 \\
\text { E7 }\end{array}$ \\
\hline $\mathrm{P}(\mathrm{Mo})=50 \mathrm{~W}$ & 3.387 & $\begin{array}{c}2.371 \\
\text { E-5 }\end{array}$ & 0.913 & 1.992 & $\begin{array}{l}1.11 \\
\text { E-5 }\end{array}$ & 0.525 & $\begin{array}{c}2.473 \\
\text { E5 }\end{array}$ & $\begin{array}{l}3.46 \\
\text { E-13 }\end{array}$ & $\begin{array}{l}2.125 \\
\text { E-11 }\end{array}$ \\
\hline $\mathrm{P}(\mathrm{Mo})=90 \mathrm{~W}$ & 3.760 & $\begin{array}{c}2.907 \\
\text { E-5 }\end{array}$ & 1 & 1.666 & $\begin{array}{c}1.355 \\
\text { E-4 }\end{array}$ & 0.809 & 8.367 & $\begin{array}{c}4.539 \\
\text { E-5 }\end{array}$ & $\begin{array}{c}1.799 \\
\text { E4 }\end{array}$ \\
\hline uncoated & 4.031 & - & - & - & $\begin{array}{c}2.514 \\
\text { E-5 }\end{array}$ & 0.856 & $\begin{array}{c}1.224 \\
\mathrm{E} 4\end{array}$ & . & - \\
\hline
\end{tabular}
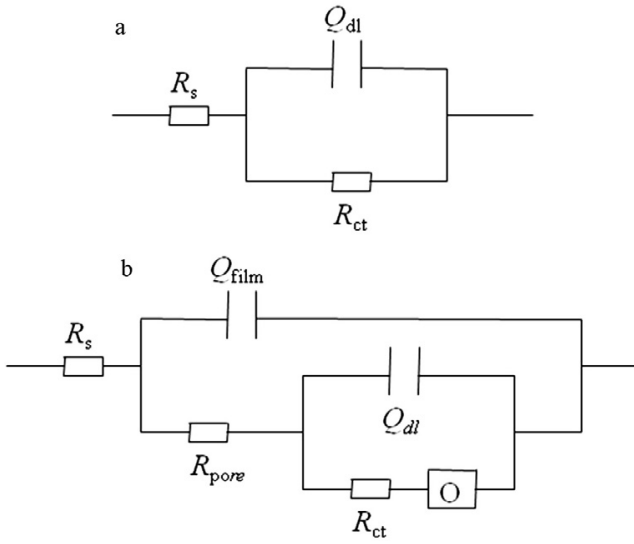

Figure 7: Equivalent-circuit diagram, used in the experiment

Therefore, the cotangent diffusion element $(O)$ should be adopted in series with the charge-transfer resistance.

In Figure 6b, the $\mathrm{CDC}$ is $R(Q(R(Q(R O))))$. The capacitance $\left(Q_{\text {film }}\right)$ and the charge-transfer resistance for the porosity of the film $\left(R_{\text {pore }}\right)$ are included as additional elements to the equivalent circuit, as shown for the substrate in Figure 7a. From the EIS data given in Table 6, the $R_{\mathrm{ct}}$ increases in the following order: $20 \mathrm{~W}, 90 \mathrm{~W}$, uncoated, $50 \mathrm{~W}, 30 \mathrm{~W}$. This indicates that the samples with a higher Mo-target power show a better corrosion resistance. With the increase of the power of the Mo target, the solid solubility also increases. When the power of the Mo target is $30 \mathrm{~W}$, the solid solubility in the medium has good corrosion resistance. But, with a continuous increase in the Mo-target power, the solubility increases and the lattice distortion occurs, leading also to an increase in defects. In the case of the sample with $50 \mathrm{~W}$, the $R_{\text {pore }}$ shows a gradual decrease with the increase in the Mo-target power.

\section{CONCLUSIONS}

ZrMoN films are deposited on SS304 with an RF magnetron-sputtering system. The total thickness of a film is $2.3 \mu \mathrm{m}$ and the growth orientation of a $\mathrm{ZrMoN}$ film is mainly in the (llll $\left.1 \begin{array}{lll}1 & 1\end{array}\right)$ direction. Static-water con- tact-angle results show that the $\mathrm{ZrMoN}$ films have a low surface wettability, which is beneficial to the water management of a PEMFC stack. As the Mo-target power increases from $20 \mathrm{~W}$ to $90 \mathrm{~W}$, the $E_{\text {corr }}$ shifts towards the positive side (from -0.395 to -0.0347 ), the $i_{\text {corr }}$ decreases gradually from 18.1 to 0.0169 , and the $R_{\mathrm{p}}$ gradually improves. As an overall evaluation, the power of the Mo target is $30 \mathrm{~W}$. A coated sample displays the best corrosion resistance in the cathode of the PEMFC environment when the power of the Mo target is considered, which indicates that with an increase of the power of the Mo target, the solid solubility also increases. However, with a continuous increase of the Mo-target power, the solubility increases and a lattice distortion also occurs, leading to an increase in defects. Through the study of PEMFC bipolar-plate materials, ZrMoN-coated stainless steel can be proven as a good candidate.

\section{Acknowledgement}

This work was financially supported by the Natural Science Foundation of the Jiangsu Province, China (No.BK20141292).

\section{REFERENCES}

${ }^{1}$ L. Carrette, K. A. Friedrich, U. Stimming, Fuel cells-fundamentals and applications, Fuel Cells, 1 (2001) 1, 5-39, doi:10.1002/16156854(200105)1:15

${ }^{2}$ G. O. Collantes, Incorporating stakeholders perspectives into models of new technologies diffusion: the case of fuel cell vehicles, Technol. Forecasting Soc. Change, 74 (2007) 3, 267-80, doi:10.1016/ j.techfore.2006.02.001

${ }^{3}$ Y. Wang, K. S. Chen, J. Mishler, A review of polymer electrolyte membrane fuel cells: technology, applications, and needs on fundamental research, Appl. Energy, 88 (2011), 981-1007, doi:10.1016/ j.apenergy.2010.09.030

${ }^{4}$ T. Sasabe, S. Tsushima, In-situ visualization of liquid water in an operating PEMFC by soft X-ray radiography, International Journal of Hydrogen Energy, 35 (2010) 20, 11119-11128, doi:10.1016/ j.ijhydene.2010.06.050

${ }^{5}$ D. Q. Mei, M. Qian, B. H. Liu et al., A microreactor with micropin-fin arrays for hydrogen production via methanol steam reforming, J. Power Sources, 205 (2012), 367-76, doi:10.1016/j.jpowsour. 2011.12.062 


\section{MATERIALI IN TEHNOLOGIJE/MATERIALS AND TECHNOLOGY (1967-2017) - 50 LET/50 YEARS}

\section{B. ZHENG, X. CHEN: ZrMoN FILMS ON 304 STAINLESS STEEL AS BIPOLAR PLATES FOR PEMFCs ...}

${ }^{6}$ Min Zhang, Kwang Ho Kim, Zhigang Shao et al., Effects of Mo content on microstructure and corrosion resistance of arc ion plated Ti-Mo-N films on 316L stainless steel as bipolar plates for polymer exchange membrane fuel cells, Journal of Power Sources, 253 (2014), 201-204, doi:10.1016/j.jpowsour.2013.12.075

A. Kumar, R. G. Reddy, Materials and design development for bipolar/end plates in fuel cells, Journal of Power Sources, 129 (2004), 62-67, doi:10.1016/j.jpowsour.2003.11.011

${ }^{8}$ M. J. Kelly, G. Fa?lek, J. O. Besenhard et al., Contaminant absorption and conductivity in polymer electrolyte membranes, Journal of Power Sources, 145 (2005), 249-252, doi:10.1016/j.jpowsour. 2005.01.064

${ }^{9}$ S. P. Mani, A. Srinivasan, N. Rajendran, Effect of nitrides on the corrosion behaviour of $316 \mathrm{~L}$ SS bipolar plates for Proton Exchange Membrane Fuel Cell (PEMFC), International Journal of Hydrogen Energy, 40 (2015) 8, 3359-3369, doi:10.1016/j.ijhydene.2014.12.108

${ }^{10} \mathrm{H}$. A. Jehn, Improvement of the corrosion resistance of PVD hard coating substrate systems, Surface and Coatings Technology, 125 (2000), 212, doi:10.1016/S0257-8972(99)00551-4

${ }^{11}$ S. H. Yao, Y. L. Su, W. H. Kao et al., Wear behavior of DC unbalanced magnetron sputter deposited $\mathrm{ZrCN}$ films, Materials Letters, 59 (2005) 26, 3230-3233, doi:10.1016/j.matlet.2005.04. 064

${ }^{12}$ B. D. C. Bell, S. T. Murphy, P. A. Burr et al, The influence of alloying elements on the corrosion of $\mathrm{Zr}$ alloys, Corrosion Science, 105 (2016), 36-43, doi:10.1016/j.corsci.2015.12.022

${ }^{13}$ A. Pardo, M. C. Merino, A. E. Coy et al, Effect of Mo and Mn additions on the corrosion behaviour of AISI 304 and 316 stainless steels in $\mathrm{H}_{2} \mathrm{SO}_{4}$, Corrosion Science, 50 (2008), 780-794, doi:10.1016/ j.corsci.2007.11.004

${ }^{14} \mathrm{R}$. Qvarfort, Some observations regarding the influence of molybdenum on the pitting corrosion resistance of stainless steels, Corrosion Science, 40 (1998), 21-223, doi:10.1016/S0010-938X(97)00118-2

${ }^{15}$ M. Kaneko, H. S. Isaacs, Effects of molybdenum on the pitting of ferritic- and austenitic-stainless steels in bromide and chloride solutions, Corrosion Science, 44 (2002), 1825-1834, doi:10.1016/ S0010-938X(02)00003-3

${ }^{16}$ J. Piippo, B. Elsener, H. Bohni, Electrochemical characterization of TiN coatings, Surface and Coatings Technology, 61 (1993), 43, doi:10.1016/0257-8972(93)90200-8

${ }^{17}$ C. Liu, Q. Bi, A. Matthews, EIS comparison on corrosion performance of PVD TiN and CrN coated mild steel in $0.5 \mathrm{~N} \mathrm{NaCl}$ aqueous solution, Corrosion Science, 43 (2001), 1953-1961, doi:10.1016/ S0010-938X(00)00188-8

${ }^{18}$ S. H. Ahn, Y. S. Choi, J. G. Kim et al., A study on corrosion resistance characteristics of PVD Cr-N coated steels by electrochemical method, Surface and Coatings Technology, 150 (2002), 319, doi:10.1016/S0257-8972(01)01529-8

${ }^{19}$ Y. Fu, G. Lin, M. Hou et al., Carbon-based films coated 316L stainless steel as bipolar plate for proton exchange membrane fuel cells, International Journal of Hydrogen Energy, 34 (2009), 453-458, doi:10.1016/j.ijhydene.2008.10.068

${ }^{20}$ B. Wu, G. Lin, Y. Fu, M. Hou, B. Yi, Chromium-containing carbon coating on stainless steel as bipolar plates for proton exchange membrane fuel cells, International Journal of Hydrogen Energy, 35 (2010), 13255-13261
${ }^{21}$ J. Barranco, F. Barreras, A. Lozano, M. Maza, Influence of CrN-coating thickness on the corrosion resistance behaviour of aluminium-based bipolar plates, Journal of Power Sources, 196 (2011), 4283-4289, doi:10.1016/j.jpowsour.2010.11.069

${ }^{22}$ B. C. Cha, Y. Z. You, S. T. Hong et al., Nitride films as protective layers for metallic bipolar plates of polymer electrolyte membrane fuel cell stacks, International Journal of Hydrogen Energy, 36 (2011), 4565-4572, doi:10.1016/j.ijhydene.2010.04.116

${ }^{23}$ H. S. Choi, D. H. Han, W. H. Hong et al., (Titanium, chromium) nitride coatings for bipolar plate of polymer electrolyte membrane fuel cell, Journal of Power Sources, 189 (2009), 966-971, doi:10.1016/j.jpowsour.2008.12.060

${ }^{24}$ L. Wang, D. O. Northwood, X. Nie et al., Corrosion properties and contact resistance of TiN, TiAlN and CrN coatings in simulated proton exchange membrane fuel cell environments, Journal of Power Sources, 195 (2010), 3814-3821, doi:10.1016/j.jpowsour.2009. 12.127

${ }^{25}$ P. Yi, L. Peng, L. Feng et al., Performance of a proton exchange membrane fuel cell stack using conductive amorphous carbon-coated 304 stainless steel bipolar plates, Journal of Power Sources, 195 (2010) 20, 7061-7066, doi:10.1016/j.jpowsour.2010.05.019

${ }^{26}$ V. K. W. Grips, H. C. Barshilia, V. E. Selvi et al., Electrochemical behavior of single layer $\mathrm{CrN}$, TiN, TiAlN coatings and nanolayered Ti Al N/Cr N multilayer coatings prepared by reactive direct current magnetron sputtering, Thin Solid Coatings, 514 (2006), 204-211, doi:10. 1016/j.tsf.2006.03.008

${ }^{27}$ A. P. Yadav, F. Suzuki, A. Nishikata et al., Investigation of atmospheric corrosion of $\mathrm{Zn}$ using ac impedance and differential pressure meter, Electrochimica Acta, 49 (2004), 2725-2729, doi:10.1016/ j.electacta.2004.01.033

${ }^{28}$ Y. Fu, G. Q. Lin, M. Hou et al., Carbon-based films coated 316L stainless steel as bipolar plate for proton exchange membrane fuel cells, International Journal of Hydrogen Energy, 34 (2009) 1, 405-409, doi:10.1016/j.ijhydene.2008.10.068

${ }^{29} \mathrm{H}$. Altun, S. Sen, The effect of PVD coatings on the corrosion behaviour of AZ91 magnesium alloy, Materials and Design, 27 (2006), 1174-1179, doi:10.1016/j.matdes.2005.02.004

${ }^{30}$ A. S. Korhonen, Corrosion of thin hard PVD coatings, Vacuum, 45 (1994) 10-11, 1031-1034, doi:10.1016/0042-207X(94)90015-9

${ }^{31}$ C. H. Hsu, M. L. Chen, K. L. Lai, Corrosion resistance of TiN/ TiAlN-coated ADI by cathodic arc deposition, Materials Science and Engineering A, 421 (2006), 182-190, doi:10.1016/j.msea.2005. 12.014

${ }^{32}$ D. A. Jones, Principles and Prevention of Corrosion, 2nd Edition, Prentice-Hall, Upper Saddle River, NJ, 43 (1992) 4, 8-10, doi: 9780133599930

${ }^{33}$ F. Lang, Z. Yu, The corrosion resistance and wear resistance of thick TiN coatings deposited by arc ion plating, Surface \& Coatings Technology, 145 (2001), 80-87, doi:10.1016/S0257-8972(01)01284-1

${ }^{34}$ DOE Hydrogen Program, FY 2006 Annual Progress Report, 2006, http://www.hydrogen.energy.gov/pdfs/progress06

${ }^{35}$ H. Dong, Y. Sun, T. Bell, Enhanced corrosion resistance of duplex coatings, Surface \& Coatings Technology, 90 (1997) 1-2, 91-101, doi:10.1016/S0257-8972(96)03099-X 